\title{
Adèle Toussaint-Samson em dose dupla
}

\author{
A Parisian in Brazil. The Travel \\ Account of a Frenchwoman in \\ Nineteenth-Century. Rio de \\ Janeiro.
}

TOUSSAINT-SAMSON, Adèle.

Edited and introduced by June E. Hahner.
Translated by Emma Toussaint.
Wilington, Delaware: Scholarly
Resources, $2001.121 \mathrm{p}$.

Depois de esperar mais de século por traduções para outras línguas, a escritora e tradutora Adèle Toussaint-Samson é homenageada no século XXI com duas traduções: uma para o inglês e outra para o português, realizadas por profissionais competentes e apreciadoras de seu texto, publicado em francês, em 1883.

June Hahner, pioneira de estudos sobre a mulher na América Latina, freqüentadora assídua dos arquivos paulistas e cariocas, com bagagem bibliográfica sobre as jornalistas mulheres, desde 1978, ampliou os conhecimentos biográficos sobre Mme. Toussaint embora tenha sido iludida pelo nome da tradutora do livro para o inglês, Emma Toussaint, supondo-a filha da autora estudada.

Maria Inês Turazzi, arquiteta e historiadora, que cuida do acervo Paulo Geyer, colocado hoje no Museu Imperial de Petrópolis, onde existe o único original português do livro de $\mathrm{Mme}$. Toussaint-Samson, teve o privilégio de estudar na França tendo acesso, entre outros, aos arquivos do Figaro e pôde aproveitar os conhecimentos de June Hahner sobre a publicação no Jornal de Commercio do Rio de Janeiro para comparar a tradução de $1883 \mathrm{com}$ a atual do livro recusado por quatro editores franceses.

Essa dificuldade de publicar em meados do século XIX em um gênero eminentemente masculino, como os livros de viagem, não foi exclusiva de Mme. Toussaint-Samson. O que a singularizou, entre as demais mulheres viajantes que escreveram livros sobre o Brasil, foi ser já uma escritora, dos círculos ligados à Comedie

\author{
Uma parisiense no Brasil.
}

TOUSSAINT-SAMSON, Adèle.

Tradução do original francês: Maria Lucia Machado.

Prefácio: Maria Inês Turazzi.

Rio de Janeiro: Editora Capivara, 2003. $190 \mathrm{p}$.

Française, que se propôs a publicar um livro sobre a vida cotidiana, nos 12 anos em que viveu no Rio de Janeiro, declarando ter vindo para fazer fortuna.

A própria exclusão desse prefácio pelo tradutor brasileiro é muito significativa. O senhor A. E. C. C., autor de livros didáticos para o ensino primário, é muito severo em relação aos enganos de geografia e de redação, como diversos brasileiros que se sentiram agredidos pelas observações superficiais feitas por estrangeiros sobre o que presenciaram no Brasil. A. E. C. C. acrescenta a essa predisposição geral uma arrogância marcante referente à autora. Para ele, os esforços feitos junto a editores franceses e à população brasileira na França não apresentam o interesse e a atualidade que têm para estudiosos das relações de gênero.

Quando li o livro, o que inicialmente chamou - meu interesse foi a contradição entre uma escritora que declarava ter vindo fazer fortuna e o belo texto, as traduções apresentadas de poetas brasileiros e o prazer de ler José de Alencar. Em seguida, as observações feitas a respeito das mulheres encontradas no Brasil, muito mais penetrantes que as de outros viajantes, homens e mulheres.

Em muitos trabalhos tive oportunidade de citar o trecho que mais me chamou a atenção, o que fala sobre sua percepção do trabalho feminino contínuo e que pretende ser invisível para os de fora. Mesmo havendo mulheres livres, brancas, mulatas e negras no Brasil daquela época, a maioria dos viajantes distinguiu a escrava como um burro de carga e a branca 
como preguiçosa e autoritária. É verdade que Mme. Toussaint-Samson viveu no Rio de Janeiro durante 12 anos, tinha um marido nascido no Brasil e que falava português como um habitante da terra, e ela não passou pelo Brasil ignorando as línguas faladas e suas variações. Inspirada pela penetração de Mme. Toussaint-Samson ao perceber a atividade incessante da mulher é que criei a categoria de intervalos cíclicos para a condição feminina no século XIX, em vez de cair na diacronia de falar de lazer.

Tomei conhecimento de Mme. Toussaint quanto realizei os livros $A$ mulher brasileira no Rio de Janeiro, no Século XIX, um índice de referências de livros de viajantes estrangeiros, publicado em 1982 pela Fundação Carlos Chagas, e Condição feminina no Rio de Janeiro (Século XIX), uma antologia crítica de textos de viajantes estrangeiros que visitaram o Brasil que já teve duas edições em 1984, publicado pela HUCITEC. Meus trabalhos eram intertextuais, referindo-se às primeiras impressões causadas pelo Rio de Janeiro nos visitantes, e seu objeto era dar visibilidade às mulheres que habitavam o Brasil, e não aos autores dos livros de viagem.

Mesmo tendo tido contacto com a família real e sendo convidada para suas recepções, Adèle Toussaint-Samson não ignorou a população das demais camadas sociais e tentou até esclarecer à mulher de um administrador sobre o direito que tinha de fugir à situação humilhante de ser preterida pelo marido, que preferia as escravas mulatas.

É também verdade que, vindo de Paris, então o centro da 'civilização', e de uma família de artistas, tinha uma perspectiva avançada sobre a situação da mulher, podendo participar e pensar sobre inúmeras questões, impensáveis mesmo entre mulheres de países europeus e até na própria França, fora de Paris. Essa segurança permite que interfira no comportamento de uma vizinha que açoitava as escravas por qualquer engano. Ela conta essas 'interferências' com muito humor, ridicularizando os resultados: a vizinha passa a amordaçar as escravas antes de açoitálas, para que os gritos não chegassem à vizinhança.

Os famosos mal-entendidos lingüísticos entre estrangeiros e brasileiros eram constantes e, mesmo agora, ocorrem com freqüência, e fazer fortuna como professor de dança ou de línguas parece hoje um disparate, mesmo considerando fortuna como sinônimo de sorte. Ocorre que, na capital de um país recém-independente e que iniciava sua re-europeização, a dança nos salões e a língua francesa eram itens educacionais da maior importância, mesmo para a família imperial. Por isso, esses mal-entendidos lingüísticos e culturais também são ridicularizados sem rancor ou desprezo. Nesse aspecto Mme. Toussaint tem também a sensibilidade de apreciar o encanto do português falado no Brasil, com sua entonação nasal modificada e o acréscimo de diminutivos. Aliás, alguns de seus erros de grafia, que tanto irritaram seu primeiro tradutor, provêm do fato de grafar palavras por sua eufonia.

Outra diferença sensível de Mme. Toussaint foi o fato de ela se arriscar a uma viagem transatlântica em veleiro com um filho que ainda amamentava. Ela assinala o respeito que essa situação impôs aos passageiros do navio. Embora não se detenha muito a contar as 'gracinhas' dos filhos, conta esta na primeira vinda ao Rio, muito expressiva: acordado pelo barulho e pelo balanço do barco, Paul se queixa: "Não quero ficar numa cama que se mexe; quero dormir na minha caminha que não se mexe. Mamãe, vou vomitar".

Ainda uma outra diferença, talvez atribuível à longa permanência no Brasil, com viagens intercaladas à França, foi a decepção apresentada ao voltar. Apesar da alegria de estar de volta, seu país lhe pareceu triste e cinzento em comparação com o Brasil. Pareceu-lhe de

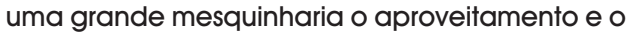
cultivo de cada pedaço de terra. Lamentou a perda dos imensos horizontes, que a natureza se encarregava de enriquecer e embelezar. Teve dificuldade para se re-acostumar à vida parisiense, tão estreita, apertada, onde cada bocado na mesa é contado, onde até o ar parece medido. Teve a convicção de que, quando a "alma impregnou-se fortemente da presença das grandes obras de Deus, não se pode mais compreender a vida factícia (sic) de nossas cidades" (p. 180).

A par dessas diferenças, Mme. ToussaintSamson tinha o conhecimento e os preconceitos de seu tempo. As limitações apontadas em quase todos os livros de viajantes também a atingem. Registra dados exteriores da vida cotidiana, mas esse registro torna-se vulnerável quando tenta interpretar relações e instituições sociais. 0 viajante, tanto o que pretendia transformar a terra visitada em mercado consumidor de seu país de origem, quanto o que pretendia fugir dos aspectos negativos do capitalismo industrial por uma aproximação com a natureza, tinha uma postura de 'civilizado' diante de uma população 'atrasada'. Mme. Toussaint-Samson identificavase fundamentalmente com a cultura européia e os padrões de avaliação dos homens e de sua 
produção de acordo com o êxito ou o fracasso. No caso da avaliação de um grupo social diversificado, com maneiras de viver das quais o observador tem apenas amostras concretas fragmentárias, nem sempre representativas, essa avaliação constitui uma fonte de preconceitos e mal-entendidos fatais.

Mme. Toussaint-Samson demonstra diversas vezes horror à escravidão e à crueldade que desencadeia, intercede a favor de uma escrava fugida, chega a solicitar a um compadre que não açoite seus escravos, mas tem diversas manifestações de preconceito racial e de atitudes de superioridade diante de negros, mulatos e mesmo das mulheres que encontrou. Porém, não deixou de observar os preconceitos dos brasileiros, em relação às mulheres que saiam à rua sozinhas, considerando-as 'madames'. Reflete também que as 'cocotes' não são das menores exportações francesas.

Trata-se de um livro muito bem escrito e revelador de aspectos da vida do Rio de Janeiro que nem todos dos mais diversos visitantes foram capazes de apreender. Foi um grande prazer reencontrar Mme. Toussaint-Samson 20 anos após conhecê-la.

Miriam Lifchitz Moreira Leite Universidade de São Paulo 